EGU21-3268

https://doi.org/10.5194/egusphere-egu21-3268

EGU General Assembly 2021

(c) Author(s) 2021. This work is distributed under

the Creative Commons Attribution 4.0 License.

\title{
A stable oxygen isotope record of weather-timescale variability in the Eocene greenhouse world, using the giant marine gastropod Campanile giganteum
}

Nick Van Horebeek ${ }^{1}$, Johan Vellekoop ${ }^{1,2}$, Alexander J. Clark' ${ }^{1}$, Niels J. de Winter ${ }^{2,3}$, Yannick Stroobandt ${ }^{1}$, and Robert P. Speijer ${ }^{1}$

'Department of Earth and Environmental Sciences, Division Geology, KU Leuven, Celestijnenlaan 200E, 3001 Leuven, Belgium

${ }^{2}$ Department of Chemistry, Analytical, Environmental and Geo- Chemistry, Vrije Universiteit Brussel, Pleinlaan 2, 1050

Brussels, Belgium

${ }^{3}$ Department of Geosciences, Universiteit Utrecht, Vening Meineszgebouw A, Princetonlaan 8a, 3584 CB Utrecht,

Netherlands

Instrumental climate data are only available for the last few hundred years. To extend this record back in time, climate proxies are used. However, on the geological timescale, the temporal resolution of most paleoclimate records does not provide information about seasonality, let alone events on the weather-timescale. These weather-timescale events are becoming more frequently integrated in models to predict future climate change, but reconstructions of variability with such short timescales in the geological record are extremely rare.

A recent study by de Winter et al. (2020) has revealed that the Eocene giant marine gastropod Campanile giganteum (Lamarck, 1804) had growth rates exceeding $600 \mathrm{~mm} / y e a r$ along the helix, far exceeding those of most other modern and fossil molluscs. With such high growth rates, these giant gastropods have the unique potential to record weather-timescale variability in the Eocene greenhouse world. Therefore, we generated a high-resolution ( $\mathrm{mm}$-scale) $\delta^{18} \mathrm{O}$ record on a wellpreserved specimen of $C$. giganteum from the Paris Basin in Fleury-la-Rivière, France, in order to generate a unique ultra-high resolution record of intra-annual, weather-timescale variability in the Eocene. Our preliminary results show a clear seasonal pattern with $\delta^{18} \mathrm{O}$ values ranging between $0.1 \%$ and $-2.5 \%$, superimposed by weekly variations of up to $0.5 \%$. This could provide insights in weather patterns in the Eocene greenhouse climate and potentially allow the identification of extreme weather events.

\section{Reference}

de Winter N.J., Vellekoop J., Clark A.J., Stassen P., Speijer R.P., Claeys P., (2020) The Giant Marine Gastropod Campanile Giganteum (Lamarck, 1804) as a HighपResolution Archive of Seasonality in the Eocene Greenhouse World., Geochemistry, Geophysics, Geosystems, 21(4), 
https://doi.org/10.1029/2019GC008794 